\title{
NANOSILVER GEL VERSUS ZINC OXIDE-ALLIUM SATIVUM OIL PASTE AS OBTURATION MATERIALS FOLLOWING PARTIAL PULPECTOMY OF PRIMARY MOLARS: AN IN VIVO STUDY
}

\author{
Abdelmoaty A*, El-Bayoumy $\mathrm{S}^{* *}$, El-Mansy $\mathrm{T}^{* * * *}$
}

\begin{abstract}
Objective: The aim of this study was to evaluate the clinical and radiographic success of nanosilver gel in paste form versus zinc oxide allium sativum oil paste as obturation materials following partial pulpectomy in primary molar. Subjects and methods: Forty eight primary molars of forty eight children aged between 4 and 8 years with pulpally involved primary molars requiring root canal procedures were equally divided to 3 groups and treated with nanosilver paste zinc oxide allium sativum oil paste and zinc oxide eugenol as obturation materials following partial pulpectomy procedure. The subjects were followed up clinically and radiographically at one week, 6 weeks and 3 months, respectively. Results: The results showed that the clinical and radiographic success rates of nanosilver gel in paste form and zinc oxide allium sativum oil paste over 3 months periods of observation were $100 \%$ whereas, for zinc oxide allium sativum oil and zinc oxide eugenol paste, the results were $87.5 \%$ and $81.25 \%$, respectively. Conclusion: On the basis of the overall success rates of all the three obturation material, following order of performance can be inferred clinical and radiographic success :- nanosilver paste $>$ zinc oxide allium sativum paste $>$ zinc oxide eugenol paste.
\end{abstract}

Keywords: Nanosilver; allium sativum; partial pulpectomy; primary molars

\section{INTRODUCTION}

Preserving deciduous teeth near to their shedding time is essential for many aspects such as the child's growth and development, esthetic, functional, psychological, and dental arch integrity aspects ${ }^{(1)}$. Necrotic pulp is one of the sequelae of dental caries or trauma which may lead to abscess, fistula or sinus formation ${ }^{(2)}$. The complex nature of the deciduous root canal system facilitates the spread of pathogenic microbes through lateral and accessory canals, dentinal tubules, apical ramifications, and the possibility of harming the tooth germ of permanent successor, and subsequently, these barriers make total removal of necrotic tissue by instrumentation alone impossible ${ }^{(3)}$. Root canal procedure for non-vital pulp tissue that is irreversibly infected or necrotic due to caries or trauma is partial pulpectomy.

It is generally impossible to achieve neither a total pulpectomy nor a complete negotiation of accessory canals in primary molars that will then become, by force of circumstances, a partial pulpectomy. Therefore, the use of a chemical and pharmacological shaping based on antiseptic and antibiotic properties of endodontic irrigants and medications should be used ${ }^{(4)}$. For an ideal root canal filling material, the following properties are required: (1) Resorbability, (2) antiseptic property, (3) noninflammatory and nonirritating to the underlying permanent tooth germ, (4) radiopacity, (5) ease of insertion and removal, (6) cost effective, (7) ability

\footnotetext{
* B.D.S, 2010 G, Faculty of Dental Medicine, Misr International University.

** Professor of Pedodontics and Oral Health department, Faculty of Dental Medicine (Cairo, Boys), Al Azhar University.

*** Lecturer of Pedodontics and Oral Health department, Faculty of Dental Medicine (Cairo, Boys), Al Azhar University.
} 
to seal canal properly, (9) ability to set under wet conditions, and (10) nonstaining to the tooth ${ }^{(5)}$.

At present, the commonly used material for primary root canal fillings is non-reinforced zinc oxide eugenol. However, its usage reported many shortcomings as slow resorption, irritation to periapical tissues, necrosis of bone and cementum, and alteration in the path of eruption of succedaneous teeth led to search for its substitute ${ }^{(6,7)}$.

With the demand for new biocompatible and antimicrobial agents, nano scale material of silver nanoparticles (AgNPs) and allium sativum oil (garlic oil) may pay more attention in the coming years as alternative filling materials for pulpally involved and treated deciduous teeth. Both materials have a therapeutic effect via its broad spectrum antibacterial effect as well as its less cytotoxic effect without the development of drug resistance ${ }^{(8,9)}$.

Nanotechnology is considered to be a breakthrough in the field of medicine. It can be useful in producing advanced biomaterials with unique physical, chemical, and biological properties. This is mainly approached by enhancing surface-to-volume ratio. To control various biological processes, we can use nanomaterials with predefined geometries, surface characteristics, and mechanical strength ${ }^{(10)}$.

The antibacterial effect of AgNPs has been tested in various in vitro studies and in vivo. Microorganisms are less likely to develop resistance against silver compared with antibiotics. AgNPs interact with multiple targets in the microbial cell, such as cell membrane, enzymes, and plasmids, simultaneously providing the bacteria with the least capacity to gain resistance ${ }^{(11)}$.

Allium sativum is commonly known as garlic and is used to treat many infectious diseases due to its potent antimicrobial property because of the presence of allicin produced by enzyme allicinase which is active against a wide spectrum of bacteria ${ }^{(12)}$.It inhibits various Gram-positive and Gram-neg- ative bacteria including multidrug resistant strains of Streptococcus mutans isolated from human carious teeth ${ }^{(13)}$.

In the research to find an ideal obturating material or alternate treatment option for tooth requiring pulpectomy, the present in vivo study was undertaken to evaluate and compare clinical and radiographic success of nanosilver gel in paste form versus zinc oxide allium sativum oil paste as root canal filling materials for primary tooth.

\section{SUBJECTS AND METHODS}

The present study was a longitudinal prospective, interventional study comprising of forty eight primary non-vital molars in forty eight healthy cooperative children with age range $(4-8$ years old) indicated for partial pulpectomy. Children were selected from the Out-patient Clinic of Pedodontics Department, Faculty of Dental Medicine, Al-Azhar University. Ethical approval from the Institutional Ethical Committee and consent from the parents/ guardians were obtained.

\section{Selection criteria for primary molars:}

Clinical inclusion criteria: ${ }^{(14)}$

1. Class I or II according to American Society of Anesthesiologists (ASA)

2. Necrotic pulp tissues which may be asymptomatic or manifested with dull ache pain

3. Pathological tooth mobility

4. Percussion sensitivity

5. Swelling close to involved tooth accompanied with or without fistula

Radiographic characteristics of the root and supporting structures: ${ }^{(15,16)}$

1. The extension of radiolucency at the furcation area did not exceed the half of the space between the furcation and the permanent successor 
2. No internal root resorption

3. External root resorption (Physiologic or pathologic) limited to apical third and with at least two-thirds root intact

\section{Exclusion criteria:}

1. Uncooperativeness of child and/or parents or caregiver's behavior

2. Unrestorable tooth

3. Presence of internal root resorption

4. Presence of calcific metamorphosis inside root canals

5. Presence of root resorption exceeding one third of its length

- Selected patients were divided into three main groups according to type of different obturation materials as follows:

Group (A): 16 primary molars were received $0.03 \mathrm{mg} / \mathrm{mL}$ nanosilver gel with $50 \mathrm{~nm}$ average sized particles.

Group (B): 16 primary molars were received paste that was made by mixing zinc oxide powder with A.sativum oil "garlic extract oil".

Group (C): 16 primary molars were received ZOE paste as control group.

\section{Partial pulpectomy procedure:}

One-visit partial pulpectomy was adopted in this study for treating primary molars without acute symptoms such as cellulitis or active discharge ${ }^{(17)}$. First, local anesthetic mepivicaine hydrochloride with levonordefrin 120,000 was administrated (ALEXANDERIA Co. for PHARMACUTICS, Egypt) and rubber dam application. Then, decay was removed, access to the pulp chamber and removal of the pulp chamber roof by \# 558 non end cutting bur under air/water coolant. Coronal pulp tissue remnants were removed with sharp, sterile excavator, or large bur in a low speed handpiece. K- files used for instrumentation of root canals manually up to a \# 30 to 35 according to the estimated working length which was $2 \mathrm{~mm}$ short of radiographic apex to avoid over instrumentation ${ }^{(18)}$. Saline and $2.5 \%$ Sodium hypochlorite irrigation were used for removal of debris. Dryness was done using paper points size 35 and 40. After placement of the root canal filling material, tooth restored by stainless steel crown and glass ionomer lutting cement. All of these steps were done in all groups and the main difference was in the filling material.

\section{Preparation and placement of nanosilver gel in paste form:}

Silver nanoparticles have been prepared by chemical reduction method as reported by Turkevich et al. ${ }^{(19)}$ and, Lee and Meisel. ${ }^{20}$ A solution of silver nitrate has been used as $\mathrm{Ag}^{1+}$ ions precursor. The color of the solution slowly turned into grayish yellow, indicating the reduction of the $\mathrm{Ag}^{1+}$ ions to $\mathrm{Ag}$ nanoparticles. Propylene glycol was used as vehicle for nanosilver paste formation. It has been found to be highly beneficial in the endodontic treatment and less cytotoxic. ${ }^{21}$ It is prepared and requested from NanoTech, $6^{\text {th }}$ October, Giza, Egypt. It was loaded to a disposable plastic syringe with 26 Gauge and $5 / 8$ inch needle from "Ameco ${ }^{\circledR}$ medical industries".

\section{Preparation and placement of zinc oxide allium sativum oil paste:}

A medium consistency mixture of allium sativum oil (CAPpharm, Cairo, Egypt, [registration No.952/94]) with zinc oxide powder [Prevest DentPro $^{\circledR}$, India] was delivered to root canal using lentulo spirals (MANI Inc.).

\section{Preparation and placement of zinc oxide eugenol paste:}

A medium consistency mixture of eugenol oil with zinc oxide powder [Prevest DentPro ${ }^{\circledR}$, India] was delivered to root canal using lentulo spirals (MANI Inc.). 


\section{Clinical and radiographic evaluation:}

After treatment, clinical and radiographic evaluations were done at one week, 6 weeks and 3months. The preoperative and follow up radiographs are shown in Figures 1-3. The criteria for clinical success were absence of spontaneous pain, absence of tenderness to percussion, No abnormal mobility and absence of swelling and sinus or fistula ${ }^{(21,22)}$.
The criteria for radiographic success were no evidence of extensive pathologic root resorption; reduction or no change in pre-operative pathologic inter- radicular or periapical radiolucency and no evidence of development of new post-operative pathologic radiolucency involving succedaneous tooth germ $^{(23-26)}$. The treatment was judged to be successful when both clinical and radiographic criteria were fulfilled.

\section{Group (A) "Nanosilver paste"}

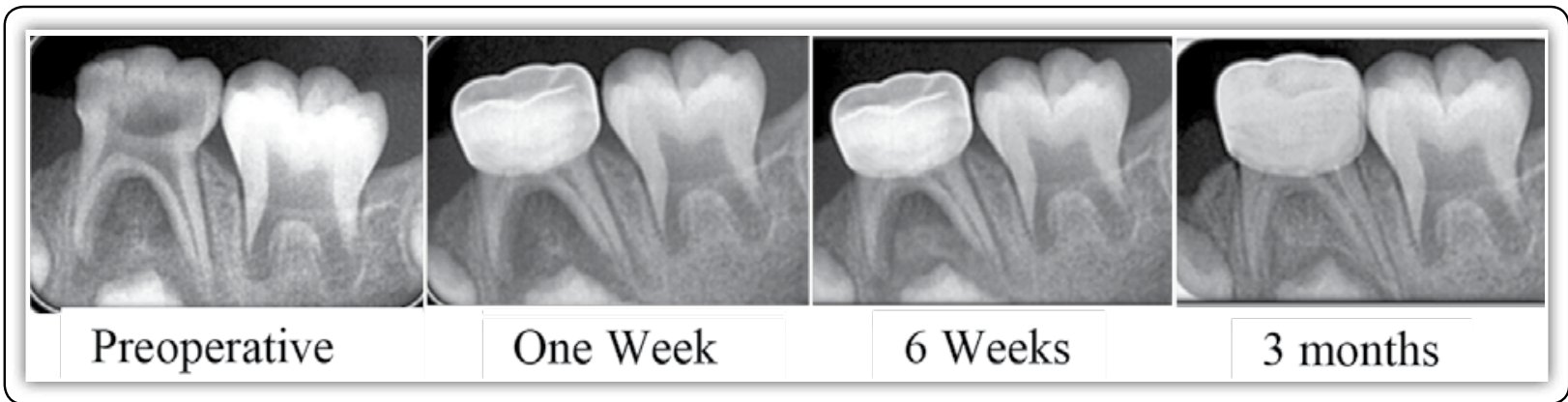

FIG (1) Radiographic assessment of badly decayed lower left primary molar of 6 years old girl

\section{Group (B) "Zinc oxide allium sativum oil paste"}

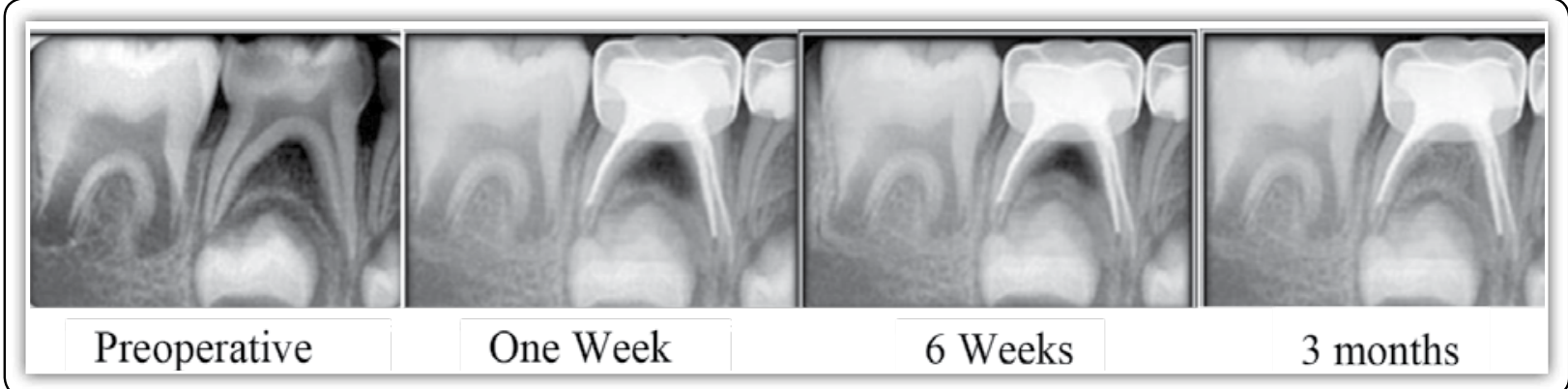

FIG (2) Radiographic assessment of badly decayed lower right primary molar of 7 years old boy.

\section{Group (C) "Zinc oxide eugenol paste"}

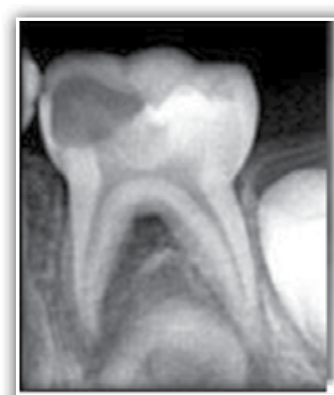

Preoperative

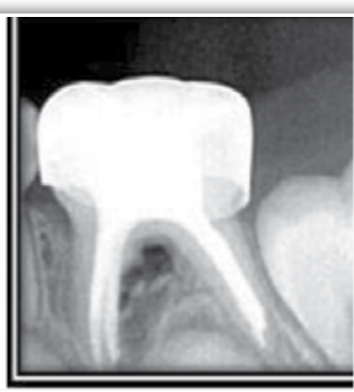

One Week

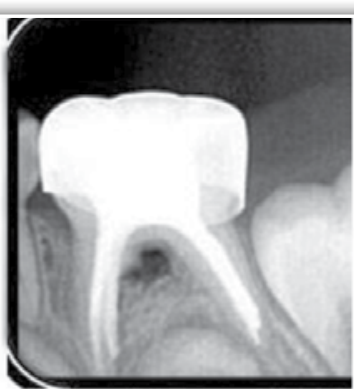

6 Weeks

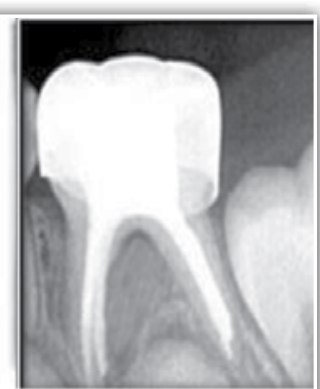

3 months

FIG (3) Radiographic assessment of badly decayed lower left primary molar of 5 years old boy. 


\section{Statistical testing:}

Statistical analysis performed using the Chisquare test. Values of $\mathrm{p} \leq 0.05$ were

\section{RESULTS}

Before treatment, the majority of the teeth in three groups presented with pain or tenderness to percussion. Pre and postoperative and follow up clinical and radiological examinations at one week, 6 weeks, and 3 months are shown in Table 2 and Table 3.

TABLE (1) Clinical evaluation preoperative and postoperative at one week, 6 weeks and 3 months

\begin{tabular}{|c|c|c|c|c|c|c|c|c|c|c|c|c|}
\hline \multirow{3}{*}{$\begin{array}{l}\text { Signs and } \\
\text { symptoms }\end{array}$} & \multirow{2}{*}{\multicolumn{3}{|c|}{ Preoperative }} & \multicolumn{9}{|c|}{ Postoperative } \\
\hline & & & & \multicolumn{3}{|c|}{1 week } & \multicolumn{3}{|c|}{6 weeks } & \multicolumn{3}{|c|}{3 months } \\
\hline & $\begin{array}{c}\text { Group } \\
\text { (A) } \\
(n=16)\end{array}$ & $\begin{array}{c}\text { Group } \\
\text { (B) } \\
(n=16)\end{array}$ & $\begin{array}{c}\text { Group } \\
(C) \\
(x=16)\end{array}$ & $\begin{array}{l}\text { Group } \\
\text { (A) } \\
(n=16)\end{array}$ & $\begin{array}{c}\text { Group } \\
\text { (B) } \\
(n=16)\end{array}$ & $\begin{array}{c}\text { Group } \\
(\mathrm{C}) \\
(n=16)\end{array}$ & $\begin{array}{l}\text { Group } \\
\text { (A) } \\
(n=16)\end{array}$ & $\begin{array}{c}\text { Group } \\
\text { (B) } \\
(v=16)\end{array}$ & $\begin{array}{c}\text { Group } \\
(\mathrm{C}) \\
(n=16)\end{array}$ & $\begin{array}{c}\text { Group } \\
\begin{array}{c}\text { (A) } \\
(n=16)\end{array}\end{array}$ & $\begin{array}{c}\text { Group } \\
\text { (B) } \\
(n=16)\end{array}$ & $\begin{array}{l}\text { Group } \\
(C) \\
(n=16)\end{array}$ \\
\hline Pain & $\begin{array}{c}15 \\
(93.7 \%)\end{array}$ & $\begin{array}{c}14 \\
(87.5 \%)\end{array}$ & $\begin{array}{c}15 \\
(93.7 \%)\end{array}$ & $\begin{array}{c}0 \\
(0 \%)\end{array}$ & $\begin{array}{c}0 \\
(0 \%)\end{array}$ & $\begin{array}{c}0 \\
(0 \%)\end{array}$ & $\begin{array}{r}0 \\
(0 \%)\end{array}$ & $\begin{array}{l}0 \\
(0 \%)\end{array}$ & $\begin{array}{c}0 \\
(0 \%)\end{array}$ & $\begin{array}{c}0 \\
(0 \%)\end{array}$ & $\begin{array}{c}2 \\
(12.5 \%)\end{array}$ & $\begin{array}{c}3 \\
(18.7 \%)\end{array}$ \\
\hline Abscess & $\begin{array}{c}7 \\
(43.7 \%)\end{array}$ & $\begin{array}{c}9 \\
(56.3 \%)\end{array}$ & $\begin{array}{c}5 \\
(31.3 \%)\end{array}$ & $\begin{array}{c}0 \\
(0 \%)\end{array}$ & $\begin{array}{c}0 \\
(0 \%)\end{array}$ & $\begin{array}{c}0 \\
(0 \%)\end{array}$ & $\begin{array}{r}0 \\
(0 \%)\end{array}$ & $\begin{array}{l}0 \\
(0 \%)\end{array}$ & $\begin{array}{c}0 \\
(05)\end{array}$ & $\begin{array}{c}0 \\
(0 \%)\end{array}$ & $\begin{array}{c}2 \\
(12.5 \%)\end{array}$ & $\begin{array}{c}3 \\
(18.7 \%)\end{array}$ \\
\hline Mobility & $\begin{array}{c}7 \\
(43.7 \%)\end{array}$ & $\begin{array}{c}8 \\
(50 \%)\end{array}$ & $\begin{array}{c}4 \\
(25 \%)\end{array}$ & $\begin{array}{c}0 \\
(0 \%)\end{array}$ & $\begin{array}{c}0 \\
(0 \%)\end{array}$ & $\begin{array}{c}0 \\
(0 \%)\end{array}$ & $\begin{array}{r}0 \\
(0 \%)\end{array}$ & $\begin{array}{l}0 \\
(0 \%)\end{array}$ & $\begin{array}{c}0 \\
(0 \%)\end{array}$ & $\begin{array}{c}0 \\
(0 \%)\end{array}$ & $\begin{array}{c}2 \\
(12.5 \%)\end{array}$ & $\stackrel{3}{(187 \%)}$ \\
\hline Pain on percussion & $\begin{array}{c}16 \\
(100 \%)\end{array}$ & $\begin{array}{c}15 \\
(93.7 \%)\end{array}$ & $\begin{array}{c}16 \\
(100 \%)\end{array}$ & $\begin{array}{c}0 \\
0 \%)\end{array}$ & $\begin{array}{c}0 \\
(0 \%)\end{array}$ & $\begin{array}{c}0 \\
(0 \%)\end{array}$ & $\begin{array}{r}0 \\
(0 \%)\end{array}$ & $\begin{array}{l}0 \\
(0 \%)\end{array}$ & $\begin{array}{c}0 \\
(0 \%)\end{array}$ & $\begin{array}{c}0 \\
(0 \%)\end{array}$ & $\begin{array}{c}2 \\
(12.5 \%)\end{array}$ & $\stackrel{3}{(18.7 \%)}$ \\
\hline
\end{tabular}

TABLE (2) Radiographic evaluation at one week, 6 weeks and 3 months

\begin{tabular}{|c|c|c|c|c|c|c|c|c|c|c|c|c|}
\hline & \multirow{2}{*}{\multicolumn{3}{|c|}{ Preoperative }} & \multicolumn{9}{|c|}{ Postoperative } \\
\hline & & & & \multicolumn{3}{|c|}{1 week } & \multicolumn{3}{|c|}{6 weeks } & \multicolumn{3}{|c|}{3 months } \\
\hline & $\begin{array}{c}\text { Group 1 } \\
(n=16),\end{array}$ & \begin{tabular}{|c|} 
Group 2 \\
$(v=16)$, \\
$n(\mathrm{No})$ \\
\end{tabular} & \begin{tabular}{|c|} 
Group 3 \\
$(p=16)$, \\
$n(0)$
\end{tabular} & \begin{tabular}{|c|} 
Group 1 \\
$(v=16)$, \\
$n(\rho v)$ \\
\end{tabular} & \begin{tabular}{|c|} 
Group 2 \\
$(\mathrm{r}=16)$, \\
$n(\mathrm{fo})$
\end{tabular} & \begin{tabular}{|c|} 
Group 3 \\
$(v=16)$, \\
$n(90)$
\end{tabular} & $\begin{array}{c}\text { Group 1 } \\
(n=16), \\
n(90)\end{array}$ & \begin{tabular}{|c|} 
Group 2 \\
$(n-16)$, \\
$n(40)$
\end{tabular} & $\begin{array}{c}\text { Group 3 } \\
(p=16), \\
n(00)\end{array}$ & \begin{tabular}{|c|} 
Group 1 \\
$(\mathrm{n}=16)$, \\
$n(\mathrm{po})$ \\
\end{tabular} & \begin{tabular}{|c|} 
Group 2 \\
$(n=16)$, \\
$n(00)$
\end{tabular} & \begin{tabular}{|c|} 
Group 3 \\
$(p=16)$, \\
$n$ (No) \\
\end{tabular} \\
\hline $\begin{array}{c}\text { Interradiculax } \\
\text { radiolucency } \\
\text { present/ same in } \\
\text { size after treatment }\end{array}$ & $\begin{array}{c}16 \\
(100)\end{array}$ & $\begin{array}{c}16 \\
(100)\end{array}$ & $\begin{array}{c}16 \\
(100)\end{array}$ & $\begin{array}{c}16 \\
(100)\end{array}$ & $\begin{array}{c}16 \\
(100)\end{array}$ & $\begin{array}{c}16 \\
(100)\end{array}$ & $\stackrel{6}{(37.5)}$ & $\begin{array}{c}8 \\
(50)\end{array}$ & $\begin{array}{l}12 \\
(75)\end{array}$ & $\begin{array}{l}0 \\
(0)\end{array}$ & $\begin{array}{c}2 \\
(12.5)\end{array}$ & $\begin{array}{c}4 \\
(25)\end{array}$ \\
\hline $\begin{array}{l}\text { Decrease in size } \\
\text { after treatment }\end{array}$ & $\cdot$ & $\cdot$ & $\cdot$ & $\cdot$ & $\cdot$ & $\cdot$ & $\begin{array}{c}10 \\
(62.5)\end{array}$ & $\begin{array}{c}8 \\
(50)\end{array}$ & $\begin{array}{c}4 \\
(25)\end{array}$ & $\begin{array}{c}16 \\
(100)\end{array}$ & $\begin{array}{c}13 \\
(81.25)\end{array}$ & $\begin{array}{c}9 \\
(56,3)\end{array}$ \\
\hline $\begin{array}{l}\text { Increase in size } \\
\text { after treatment }\end{array}$ & $\cdot$ & $\cdot$ & $\cdot$ & $\cdot$ & $\cdot$ & $\cdot$ & $\begin{array}{l}0 \\
(0)\end{array}$ & $\begin{array}{l}0 \\
(0)\end{array}$ & $\begin{array}{l}0 \\
(0)\end{array}$ & $\begin{array}{l}0 \\
(0)\end{array}$ & $\begin{array}{c}1 \\
(6.25)\end{array}$ & $\begin{array}{c}3 \\
(18.7)\end{array}$ \\
\hline
\end{tabular}




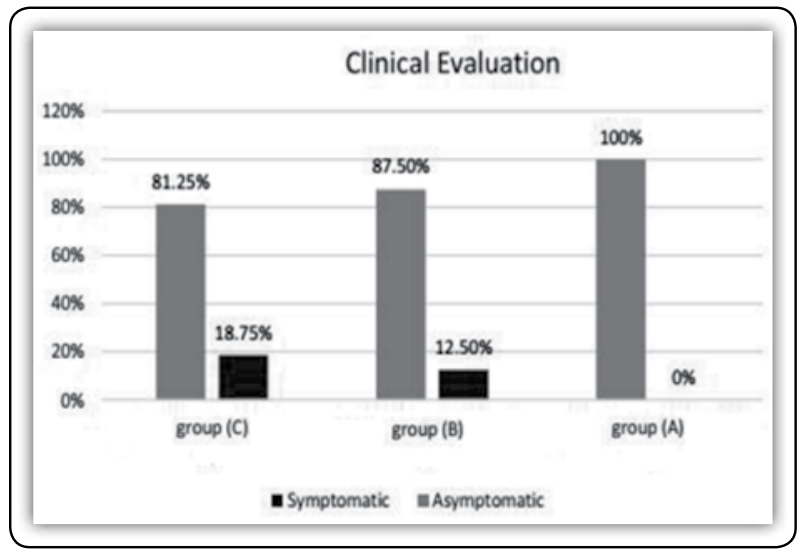

GRAPH (1) Clinical success of three groups at 3 months

\section{Postoperative clinical findings:}

At one week and 6 weeks clinical evaluation, all teeth of three groups were asymptomatic and revealed excellent clinical signs of success. Meanwhile, at 3 months all teeth of group (A) remained asymptomatic but 2 cases of group (B) failed and responded negatively to the treatment $(12.5 \%)$ and were extracted due to persistant pain, tenderness and swelling. For group (C), 3 cases failed clinically and extracted for showing clinical signs of failure. The clinical success difference was found between the three groups at end of 3 months [Graph 1]. The clinical success for three groups had no statistically significant difference was found between the three groups at the end of 3 months $[P>0.05]$ as shown in table 3 .

TABLE (3) Showing overall success and failure of clinical and radiographic evaluations

\begin{tabular}{|c|c|c|c|}
\hline Character & Group (A) & Group (B) & Group (C) \\
\hline Sub. No. & 16 & 16 & 16 \\
\hline Success cases & 16 & 14 & 13 \\
\hline $\begin{array}{c}\text { Percentage } \\
\text { Success cases }\end{array}$ & $100 \%$ & $87.5 \%$ & $81.25 \%$ \\
\hline $\begin{array}{c}\text { Failed cases } \\
\text { percentage }\end{array}$ & $0(0 \%)$ & $2(12.5 \%)$ & $3(18.75 \%)$ \\
\hline \multirow{2}{*}{\begin{tabular}{c} 
P value \\
\cline { 2 - 4 }
\end{tabular}} & 0.003 & $\mathrm{~A}: \mathrm{B}=0.015 ; \mathrm{A}: \mathrm{C}=0.032 ; \mathrm{B}: \mathrm{C}=0.302$ \\
\cline { 2 - 4 } & \multicolumn{3}{|c|}{$\mathrm{A}: \mathrm{B}: \mathrm{C}=0.305$} \\
\hline
\end{tabular}

\section{Postoperative radiographic findings:}

At the end of 3 months, radiographic success for group (A) was (100\%) as bone radiolucency decrease in size of all treated teeth. Meanwhile, radiographic success for group (B) and group (C) were $87.5 \%$ and $81.25 \%$, respectively. Bone radiolucency reduction were notices in 13 cases (81.25) and 9 cases $(56.25 \%)$ while, 1 case $(6.25 \%)$ and 3 cases $(18.75 \%)$ were shown increase in bone radiolucency for group (B) and group (C), respectively and the rest as 2 cases (12.5\%) in group (B) and 4 cases of group $(\mathrm{C})$ remained the same in size. One case of group (B) remain the same in size but show clinical failure thus, it was considered a radiographic failure [Graph 2]. Radiographic findings at end of 3 months showed statistical significance difference between group (A) versus group (B) and between group (A) and group (B); $[P<0.05]$. However, no statistical significance between the three groups $[P>0.05]$ as shown in Graph 2 and table 3.

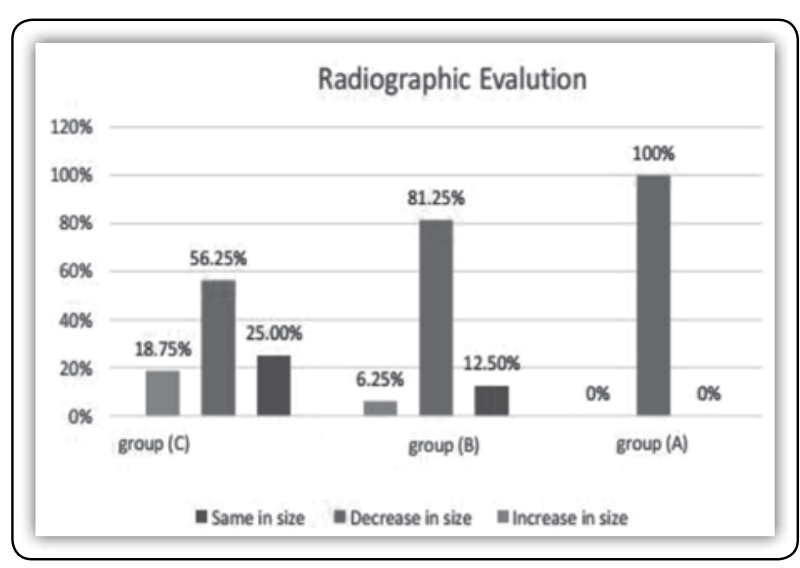

GRAPH (2) Radiographic success of three groups at 3 months

\section{DISCUSSION}

Up to the available data, the use A. sativum oil and nanosilver gel in endodontic treatment of primary teeth is limited especially the in vivo studies. These in vivo studies were conducted to 
evaluate allium sativum oil as intracanal irrigant material compared to conventional sodium hypochlorite $(\mathrm{NaOCl})$ in primary teeth ${ }^{(27)}$. The in vivo study regarding nanosilver paste was conducted to study its antimicrobial efficacy as intracanal medicament in permanent incisors in adult compared to conventional use of calcium hydroxide $\left[\mathrm{Ca}(\mathrm{OH})_{2}\right]^{(28)}$. Thus, the current study was conducted to evaluate the use of A. sativum and nanosilver as filling materials after partial pulpectomy procedure in primary molars.

The clinical and radiographic success rates of pulpectomy in primary teeth demonstrate variety among different studies. This variation might be attributed to the differences in study design in terms of; (a) inclusion and exclusion criteria; (b) followup periods; (c) pulpectomy technique, including mechanical instrumentation, irrigants and their concentration, and the filling material used for obturation; and (d) pulpectomy method (i.e., one versus two visits method). All of these variables have to be taken into consideration when comparing the current study results with other studies. However, it is useful to mention some of studies for comparison.

The clinical and radiographic result of the zinc oxide eugenol (control group) in the current study was (81.25\%) after 3 months, which slightly lower than the results of a study performed by Trairatvorakul and Chunlasikaiwan. They reported $96 \%$ and 93\% clinical and radiographic success rates at 6 and 12 months, respectively, out of 27 infected primary molars ${ }^{(29)}$.However, these results were nearly similar to the clinical and radiographic success of ZOE group which varies from $85 \%$ to $100 \%$ in one-visit pulpectomy for 20 infected primary molars ${ }^{(30)}$. On the other hand, the results of ZOE in this study were slightly higher than the study that conducted by Mortazavi \& Mesbahi which reported a $78.5 \%$ overall success rate of 52 necrotic primary teeth pulpectomized with $\mathrm{ZOE}^{(24)}$.

\section{CONCLUSION}

Within the limits of the present in vivo study, it is concluded that nanosilver gel in paste form and zinc oxide allium sativum oil paste can be used effectively as partial pulpectomy agents in deciduous teeth.

\section{REFERENCES}

1. Tunison W, Flores-Mir C, ElBadrawy H, Nassar U, ElBialy T. Dental arch space changes following premature loss of primary first molars: a systematic review. Pediatric dentistry. 2008;30:297-302.

2. McDonald E, Avery R, Stookey K, Chin R and Kowolik E. Dental caries in the child and adolescent. In: Dean A, Avery R. and McDonald E. 10 th ed. McDonald and Avery's Dentistry for the child and Adolescent. Mosby, El sevier 2016;155-173.

3. Pazelli C, Freitas C, Ito Y, Souza-Gugelmin C, Medeiros S, Nelson-Filho P. Prevalence of microorganisms in root canals of human deciduous teeth with necrotic pulp and chronic periapical lesions. Pesquisa Odontológica Brasileira. 2003 ; 17:367-71.

4. Gardner F. Partial pulpectomy, an accepted treatment for primary and young permanent teeth. Oral Surgery, Oral Medicine, Oral Pathology. 2004;3:498-503.

5. Kubota K, Golden E, Penugonda B. Root canal filling materials for primary teeth: a review of the literature. ASDC journal of dentistry for children. 1992;9:25-7.

6. Sadrian R, Coll A. A long-term followup on the retention rate of zinc oxide eugenol filler after primary tooth pulpectomy. Pediatric dentistry 1993;15:249-53.

7. Barr S. flaitz M, Hicks J. A retrospective evalution of primary molar pulpectomies. pediatr. Dent. 1991;13:4-9.

8. Alabdulmohsen A, Saad Y. Antibacterial effect of silver nanoparticles against Enterococcus faecalis. Saudi Endodontic Journal. 2017 ;7:29-33.

9. Khan L, Paulino G, Lim D, Nadela F, Yadav R, Birring J. Anti-microbial efficacy of Allium sativum against Streptococcus mutans biofilm formation on orthodontic mini-implants. Journal of Orthodontic Research. 2014 1;2:129-35.

10. Ge L, Li Q, Wang M, Ouyang J, Li X, Xing M. Nanosilver particles in medical applications: synthesis, performance, and toxicity. International journal of nanomedicine. 2014;9:2399-47. 
11. Kishen A, Shrestha A. Nanoparticles for endodontic disinfection. In: Nanotechnology in Endodontics. Cham :Springer 2015;2:97-119.

12. Goncagul G \& Ayaz E., Antimicrobial effect of garlic (Allium sativum) and traditional medicine ${ }^{e e}$. J Anim Vet Adv 2010;9:1-4.

13. Fani M, Kohanteb J, Dayaghi M. Inhibitory activity of garlic (Allium sativum) extract on multidrug-resistant Streptococcus mutans. J Indian Soc Pedod Prev Dent 2007;25:164-8.

14. American Academy of Pediatric Dentistry. Guideline on pulp therapy for primary and immature permanent teeth. Pediatr Dent. 2013;31:179-86.

15. Arikan V, Sonmez H, Sari S. Comparison of two base materials regarding their effect on root canal treatment success in primary molars with furcation lesions. BioMed research international. 2016;14:292-86.

16. Pandranki J, Vanga R, Chandrabhatla K. Zinc oxide eugenol and Endoflas pulpectomy in primary molars: 24-month clinical and radiographic evaluation. Journal of Indian Society of Pedodontics and Preventive Dentistry 2018;36:173-80.

17. Duggal S, Nooh A, High A. Response of the primary pulp to inflammation: a review of the Leeds studies and challenges for the future. European Journal of Paediatric Dentistry. $2002 ; 3: 111-4$.

18. Goerig A. \& Camp, J. Root canal treatment in primary teeth: A review. Pediatric Dentistry 1983;5, 33-7.

19. Turkevich J, Stevenson C, Hillier J. A study of the nucleation and growth processes in the synthesis of colloidal gold. Discussions of the Faraday Society. 1951;11:55-75.

20. Lee C, Meisel D. Adsorption and surface-enhanced Raman of dyes on silver and gold sols. The Journal of Physical Chemistry $1982 ; 86: 3391-5$.
21. Dogra S. Comparative evaluation of calcium hydroxide and zinc oxide eugenol as root canal filling materials for primary molars: A clinical and radiographic study. World J Dent $2011 ; 2: 231-6$.

22. Agarwal, Manisha, Mohan Das, Usha, Viswanath, Deepak. A Comparative Evaluation of Noninstrumentation Endodontic Techniques with Conventional ZOE Pulpectomy in Deciduous Molars: An in vivo Study. World J Dent 2011;2: 187-92.

23. Moskovitz M, Sammara E, Holan G. Success rate of root canal treatment in primary molars. Dent J 2005;1;33:41-7.

24. Mortazavi M, Mesbahi M. Comparison of zinc oxide and eugenol, and Vitapex for root canal treatment of necrotic primary teeth. International J Paediatr Dent 2004 ;14:417-24.

25. Fuks A, Eidelman E, Pauker N. Root fillings with Endoflas in primary teeth: a retrospective study. J Clin Pediatr Dent 2003;27:41-5

26. Coll A, Sadrian R. Predicting pulpectomy success and its relationship to exfoliation and succedaneous dentition. Pediatr Dent 1996 ;18:57-63.

27. Elheeny H. Allium sativum extract as an irrigant in pulpectomy of primary molars: A 12-month short-term evaluation. Clin Exp Dent Res. 2019;5:420-26.

28. Hassan R, A Abdou S, A. Kataia M, Ali M, Negm S. Assessment of Antimicrobial Efficacy of Silver Nanoparticles Versus Calcium Hydroxide as Intra Canal Medication (In vivo Study). Int J Microbiol res 2017;8:37-42.

29. Trairatvorakul, C., \& Chunlasikaiwan, S. Success of pulpectomy with zinc oxide-eugenol vs calcium hydroxide/iodoform paste in primary molars: A clinical study. Pediatric Dentistry 2008; 30, 303-8.

30. Barcelos R, Santos P, Primo G, Luiz RR, Maia C. ZOE paste pulpectomies outcome in primary teeth: a systematic review. Journal of Clinical Pediatric Dentistry. 2011;35:241-8. 